\title{
COMUNIDAD, ORGANIZACIÓN Y COMPLEJIDAD SOCIAL ANDINAS EN EL NORTE DE CHILE
}

\author{
Hans Gundermann ${ }^{1}$ y Jorge Iván Vergara ${ }^{2}$
}

\section{* Introducción}

Resumen

Se revisa la situación de las organizaciones aymara y atacameñas en las regiones andinas de Chile, enfatizando el papel crucial de las agencias estatales en la formación y funcionamiento de dichas organizaciones, especialmente debido a su necesidad de contar con interlocutores organizados. Se discuten los conflictos y tensiones dentro de la comunidad indígena, la más nueva y dominante figura organizativa.

Palabras claves: organización - comunidad andina - complejidad social - política étnica - norte de Chile.

This paper examines the situation of Atacameño and Aymara organizations in the Chilean Andes, focusing on the crucial role state institutions have played in their formation and functioning, as a consequence of the Chilean State's need of institutional counterparts. It also discusses the conflicts and tensions within one of the newest and most important of such organizational figures, the indigenous community.

Key words: organization - Andean community - social complexity - ethnic politics - North of Chile.

Recibido: marzo 2008. Aceptado: marzo 2009

1 Instituto de Investigaciones Arqueológicas y Museo, Universidad Católica del Norte. Gustavo Le Paige 380 , San Pedro de Atacama, CHILE. Email: hgunder@ucn.cl

2 Universidad de Antofagasta. Avenida Universidad de Antofagasta 02800, Antofagasta, CHILE. Email: jorgeivan.vergara@uantof.cl

3 Al respecto, coincidimos con Tudela (1992) pues nos encontramos ante la disolución de la comunidad tradicional (de matriz colonial) y su reelaboración en versiones modernizadas (ver también Tudela 1993).

4 Por cierto, también quechua, coya y diaguita, los pueblos indígenas andinos menores del norte del país.
El propósito de este trabajo es caracterizar el actual panorama asociativo andino, analizar las condiciones de surgimiento de las organizaciones y determinar las relaciones que se establecen entre ellas y la comunidad andina, entendida como un conjunto complejo de prácticas e instituciones sociales. Dada la amplitud social y territorial del área de estudio, nos concentraremos en el caso aymara. Nuestra revisión permitirá constatar la densa urdimbre de agrupaciones existente hoy en la zona andina y sus estrechas relaciones con las formas comunitarias de estructuración social.

Nuestra interpretación parte de la premisa de que las formas comunitarias andinas no han desaparecido ni que, como afirma Van Kessel (1992 [1981]), la comunidad aymara se haya desintegrado, sino que se ha ido transformando a lo largo del tiempo, manteniendo continuidad con el pasado pero sufriendo también muchos cambios. ${ }^{3}$ Sus transformaciones actuales ocurren en un nuevo contexto caracterizado por una considerable ampliación de los espacios sociales andinos y por un aumento de la complejidad social y cultural aymara y atacameña. ${ }^{4}$ Ello tiene gran incidencia en las características y dinámica de las organizaciones andinas que se hacen mucho más heterogéneas que en el pasado, comprenden distintos niveles sociológicos y persiguen variados objetivos. En este estudio desarrollamos el argumento de que pese a 
este proceso de diferenciación, la comunidad andina, ya sea en su forma translocalizada o local, sigue siendo la base desde la cual se han formado y crecido las nuevas organizaciones indígenas.

Para entender la dinámica organizacional andina se requiere considerar la acción del Estado como otro factor de influencia, que desde 1994 ha incentivado la formación de comunidades y asociaciones indígenas bajo los términos de la Ley Indígena 19253. En efecto, una de las exigencias a que está sometida la intervención pública en áreas indígenas es la canalización de los recursos a través de estas comunidades y asociaciones. Las agencias responsables de la ejecución de la política indígena, principalmente la Corporación Nacional de Desarrollo Indígena (CONADI) y el Programa Orígenes (inicialmente dependiente del Ministerio de Planificación y actualmente de CONADI), presionan a las agrupaciones indígenas para formar estas instituciones cuando no existen, incluso si ello puede significar, como de hecho ha ocurrido, la división de la comunidad original. No obstante dichas discrepancias, los esfuerzos de los organismos públicos por desarrollar una acción coordinada y coherente hacia los pueblos indígenas han contribuido a que las comunidades originarias, bajo este nuevo formato legal, adquirieran una creciente importancia y se hayan convertido en la principal figura organizacional en la interlocución entre los pueblos indígenas y el Estado. En suma, debemos preguntarnos cuál ha sido el impacto del Estado al promover la creación de nuevas organizaciones étnicas; como resultado de ello, su contribución a la formación de nuevas instancias de autoridad y representación política dentro de la sociedad indígena y, por último, el rol que ha jugado en la configuración del actual cuadro organizativo andino. ${ }^{5}$

\footnotetext{
5 Este análisis se origina en trabajos etnográficos realizados con organizaciones aymara, atacameñas y sus dirigentes, en Arica, Tarapacá y el Loa. Con ellos se buscó establecer perfiles históricos y de acción de la organización, la relación o ausencia de nexos con entidades sociológicas de base (localidades, comunidades), con asociaciones y organizaciones supra y translocales y con agencias estatales. Se emplearon también materiales previamente reunidos y un estudio sobre localidad y comunidad andina (Gundermann 2001). Un trabajo previo de González (1991) nos fue de gran utilidad.
}

\section{* Un panorama organizativo crecientemente HETEROGENEO Y COMPLEJO}

La comunidad local ha sido la forma de organización colectiva andina históricamente más importante. Pese a haberse debilitado en muchas de sus atribuciones y haber sufrido importantes transformaciones, se ha mantenido en el tiempo y ha seguido ocupando un lugar central. Hoy está estructurada mediante relaciones externas con agencias estatales e internas de tipo parental. Su órgano principal de gestión sigue siendo la asamblea de comuneros (Fuenzalida 1970). De la reducción colonial de indios, se pasó a inicios del siglo XX a la comunidad sucesorial en el altiplano y comunidad local (de campesinos parceleros) aymara y atacameña en las zonas de valles y oasis del norte (González et al. 1991). Para el primer caso, sus funciones principales siguen siendo la explotación coordinada de recursos productivos agropecuarios y la defensa de ese patrimonio ante las amenazas externas y los conflictos internos. Después de las rebeliones de mediados del siglo XVIII desaparecieron los cacicazgos regionales aymara, ${ }^{6}$ y con ellos cualquier nivel de organización supralocal que reuniera y convocara a un conjunto de comunidades históricas tras fines compartidos. Desde entonces, se inicia el reinado de la comunidad local (pero también su debilidad), el que se mantuvo ininterrumpidamente hasta pasada la primera mitad del siglo XX, momento en que comienza un proceso de translocalización y surgimiento de nuevas formas organizativas.?

6 Tales cacicazgos no se han establecido documentalmente para la zona atacameña y, tal parece, no existieron (Hidalgo 2004).

7 Un análisis clarificador de lo que aquí denominamos translocalización realiza Alber (1999) para un caso de la sierra central peruana. Este es re analizado más tarde por Diez (2006). Algunas distinciones de interés presenta Malengreau (1992). De este mismo autor pueden consultarse con provecho dos obras recientes (Malengreau 2004 y 2007). Análisis convergentes en algunos aspectos sustantivos con la línea de interpretación aquí seguida se encuentran en Mossbrucker (1990) y Steinhauf (1991). A su vez, Urrutia (2003) nos recuerda a Henry Dobyns y el injusto olvido al que fue sometido su esclarecedor estudio sobre las profundas transformaciones sociales que eran apreciables hace ya medio siglo en el campesinado y las comunidades andinas de Perú, cuestiones puestas de actualidad a partir de la década de 1990, momento en que las visiones idealizadas de la comunidad son objeto de discusión. 


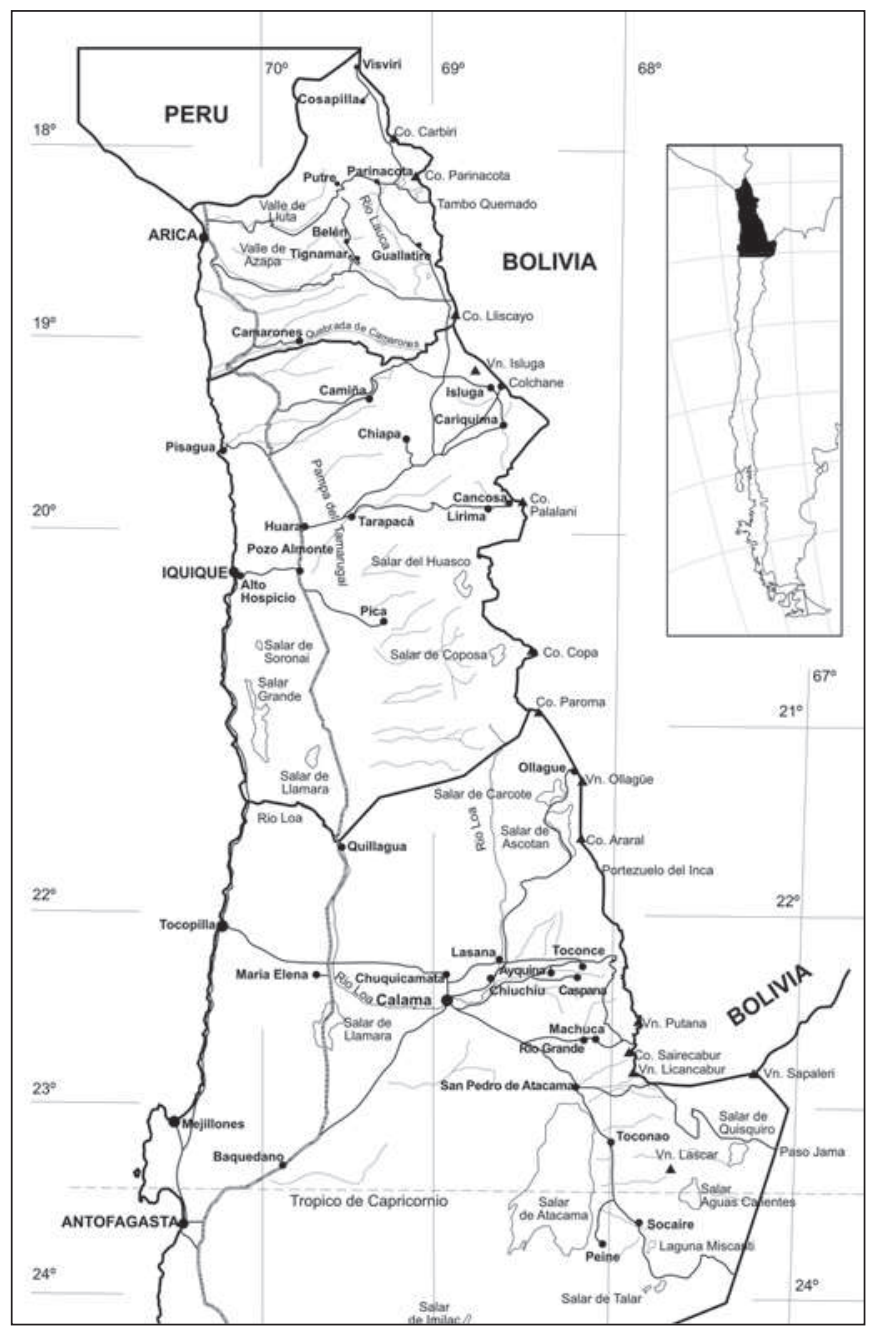

Figura 1. Mapa de las regiones de Arica-Parinacota, Tarapacá y Antofagasta, en el que se indican los principales centros urbanos y localidades mencionados en el texto.

\section{Agencias estatales y organización andina en perspectiva}

A partir de la segunda mitad del siglo pasado se producen cambios importantes en las sociedades andinas que rompen con el monopolio de la organización comunitaria. En primer lugar, se incrementa la presencia e influencia de las instituciones estatales en la cordillera y se inician las migraciones hacia otras zonas agrícolas. Estimuladas por la oferta estatal, surgen organizaciones comunitarias de base territorial que se superponen a las comunidades históricas. A mediados de la década del $60 \mathrm{e}$ inicios de los 70, muchos de esos emigrantes se incorporan al proceso de cambio en Asentamientos de Reforma
Agraria y en Cooperativas Campesinas. A su vez, las primeras oleadas de inmigrantes en su adaptación a las ciudades de Arica, Iquique y Calama, para citar solo las principales, sientan las bases sociológicas de las comunidades translocales (Figura 1).

En cuanto a lo primero, entidades tales como las juntas de vecinos, con el antecedente de las organizaciones locales de desarrollo (usualmente bajo el formato de "comités" o "centros"), son impuestas en la década de 1960 como organización de base a través de la cual crear un mecanismo de participación y canalización de demandas locales al Estado. Desde éste, a su vez, se podían facilitar las prestaciones sociales y acciones de desarrollo, a

$\mathrm{N}^{\circ} 38 / 2009$

ESTUDiOS ATACAMEÑOS

Arqueología y Antropología Surandinas 
tono con el espíritu de las políticas participacionistas y desarrollistas de la época. Las organizaciones resultantes sirvieron también para fines de control administrativo y político. Según la información con que contamos, 55\% de las juntas de vecinos de las regiones de Tarapacá y Arica-Parinacota se legalizaron entre 1970 y 1973 ; en tanto $37 \%$ lo hicieron entre 1974 y 1989 durante el régimen militar. En este último período se formaron y legalizaron la mayoría de las juntas de vecinos rurales. En un ambiente de ausencia de toda participación en los gobiernos municipales, estas organizaciones de base territorial constituyeron medios privilegiados del control político en manos de las autoridades locales designadas. ${ }^{8}$

Con la apertura política que produjo el retorno a la democracia se desarrolló la participación de base en los gobiernos locales. La estructuración de la competencia política para la elección de alcaldes y concejales en el gobierno municipal adquirió un sello localista (Gundermann 2003, 2007). Otro órgano municipal, el Consejo de Desarrollo Comunal (CODECO), supuso la participación de organizaciones "comunitarias" (en general, de tipo territorial) y funcionales. En ambos casos se abrieron posibilidades para que las comunidades o partes de ellas promovieran sus intereses e intentaran hacerlos valer en el gobierno municipal.

Sobre lo segundo, entre 1964 y 1974 bajo el alero de la Reforma Agraria en los valles bajos y Pampa del Tamarugal en la región de Tarapacá, se pusieron en funcionamiento 15 asentamientos y cooperativas campesinas ubicadas fuera del espacio indígena tradicional, hacia los valles bajos, en sectores de colonización y en propiedades previamente en poder del Estado. Con un par de excepciones, todas se formaron en la zona de Arica, y en al menos nueve, con participación de inmigrantes aymara, especialmente de aquellos provenientes de la precordillera de la provincia de Parinacota. Con la contrarreforma

8 En 1991, fuentes oficiales consignan 52 juntas de vecinos en los ocho municipios de Tarapacá y Arica-Parinacota con mayor presencia aymara. En cada municipio las juntas de vecinos se articulaban a través de las uniones comunales de juntas de vecinos. Es notable la alta participación en estas juntas (considerando la inscripción en los registros correspondientes) y su definición según una lógica comunitaria. Además, en estos mismos municipios había 29 centros de madres vigentes y 25 clubes deportivos, casi todos de fútbol (SERPLAC, I región, 1991). agraria que impone la dictadura, la tierra a la que el surgimiento de estas organizaciones estaba ligado es parcelada y entregada a título individual a sus ocupantes. Solo dos de esas organizaciones mantuvieron durante la década de 1990 algún nivel de actividad: la Agrupación Andina y la Cooperativa Sobraya, ambas ubicadas en el valle de Azapa. Durante el período que estamos comentando también existieron sindicatos de trabajadores agrícolas con visible presencia aymara (González 1991).

En zonas campesinas y de pequeños empresarios agrícolas, la acción del Estado y también el propio interés de los productores, condujo en el pasado a la creación de varias cooperativas agrícolas y campesinas. ${ }^{9}$ La participación aymara fue aquí escasa, pero en las de la precordillera andina, como la de Putre, formada en 1965, o en la ya desaparecida de Belén fundada en el mismo período, la membresía fue exclusivamente aymara. Una del mismo tipo y con una participación atacameña mayoritaria se formó en San Pedro de Atacama, en tanto otra, con una presencia indígena más limitada, se creó en Calama. Las cooperativas campesinas y agrícolas andinas incluidas, cuando no se disolvieron se volvieron inactivas por falta de capacidades de gestión y apoyo estatal. ${ }^{10}$

Un profuso y dinámico registro de organizaciones con intereses rurales agropecuarios y con una notoria presencia indígena se desarrolló en el norte durante la década de 1980. ${ }^{11}$ Se establecen sobre todo en Arica, siendo menos visibles en Iquique y prácticamente desapareciendo en la zona atacameña. En esta última, el perfil organizativo es todavía conservador, hasta la década de 1990 cuando los municipios son democratizados y llega la política indí-

9 La que reúne a los pequeños y medianos empresarios de Azapa fue fundada en 1957, y es anterior a la Reforma Agraria. De la década de 1960 es la cooperativa del oasis frutícola de Pica. Otras dos de Lluta y tres de las inmediaciones de Arica son de finales de dicha década e inicios de 1970 (González 1991).

${ }^{10}$ En la década de 1990 se retomó la iniciativa y se formó una nueva cooperativa campesina denominada Yapu Andino (chacra andina) en la zona productora de orégano de la precordillera de Parinacota (área de Belén y aldeas cercanas) y se reactivó la de Putre.

${ }^{11}$ La participación andina fue variable, componiéndose en ciertos casos exclusivamente de indígenas (p.e., Asociación Gremial de Ganaderos de General Lagos), mientras que en otros, su presencia variaba desde una mayoría (p.e., Asociación Gremial Asoagro) hasta una más limitada (p.e., Asociación Gremial de Agricultores del Valle de Lluta). 
gena. Se trata de entidades con un nivel de convocatoria más amplia que el de una comunidad en particular, en las que están involucrados socios provenientes de una zona parcelaria o varias localidades. Cuando mantienen un perfil definido como organizaciones de gestión económica, se reúnen y organizan bajo el imperativo del manejo de recursos (operación de sistemas de riego), por intereses productivos o comerciales. El componente autogestionario es alto en estos casos, diluyéndose cuando se trata de organizaciones de representación de intereses ante el Estado (p.e., para obtener apoyo técnico, créditos, medidas de excepción y franquicias de distinto tipo). Algunas fundadas con anterioridad a 1980 traen el formato de cooperativas campesinas y de pequeños agricultores. A las formadas en el período siguiente se les concedió la personería jurídica de Asociación Gremial. Esta fórmula jurídica se presta para funciones de representación y no para la autogestión organizada, lo que es coherente con la lógica privatista y anticomunitaria de las ideas liberales aplicadas a los pequeños agricultores. La presión y manipulación ejercida por las autoridades militares determinó que el accionar y las dirigencias de muchas de ellas fueran afines políticamente y, en cualquier caso, estrechamente controladas. Al no encontrar soluciones efectivas a sus demandas, redujeron su accionar o se desactivaron; en tanto, otras siguen vigentes y algunas existen solo nominalmente. ${ }^{12}$

Un caso especial lo constituyen las organizaciones encargadas de la administración de sistemas locales y microsistemas de riego resultantes de la puesta en vigor del Código de Aguas a inicios de 1980, que estipula diversos procedimientos sobre la materia. Dicho código, separa los derechos de propiedad de la tierra y los de las aguas que, de esta manera, entran al mercado. ${ }^{13}$ En las zonas

\footnotetext{
${ }^{12}$ Por ejemplo, las asociaciones gremiales Asoagro, Agricultores del Valle de Lluta, Asopecuaria de Ganaderos de Parinacota, Productores de Orégano (Belén y Tignamar), Abastecedores y Productores del Agro (Terminal Agropecuario de Iquique), Artesanas Cantathi (González 1991).

${ }^{13}$ La aplicación de esta ley en la zona aymara no ha tenido consecuencias de enajenación y acumulación de derechos sobre las aguas superficiales por parte de capitales y agentes externos, o internamente, entre aymara. En el primer caso, un intento de inscribirlas por particulares y empresas ocurrió a mediados de 1980, pero se vio frustrado por las reacciones públicas de organizaciones locales y étnicas; hoy día, una acción de este tipo llevaría a la intervención de la CONADI, uno de cuyos mandatos (precepto
}

aymara y atacameña las tierras agrícolas y las aguas de riego, así como las vegas altoandinas y las vertientes que las nutren, han estado tradicionalmente unidas y sujetas a la administración de las comunidades olocales. Bajo un régimen de participación por acciones, el número de organizaciones resultantes por localidad dependerá de las características de los sistemas de riego. Cuando se trata de un solo canal y un solo curso de agua puede mantenerse la unidad entre comunidad y organización de propietarios-administradores de las aguas de riego. $\mathrm{Si}$, en cambio, se trata de sistemas con múltiples fuentes y canales de distribución, como es lo más frecuente, el número de micro organizaciones se multiplica proporcionalmente. Es decir, al amparo de un resquicio del reglamento de la Ley de aguas surgió en zonas parcelarias con presencia aymara un tipo de organización denominada Sociedad Civil Administradora de Aguas (González 1991).14

Las organizaciones de productores campesinos que se formaron antes del período autoritario y que sobrevivieron a éste, forman parte del proceso organizacional promovido desde la acción estatal y de la Reforma Agraria. En su gran mayoría como asociaciones gremiales, las surgidas con posterioridad responden también a una iniciativa promovida por el Estado, pero sin continuidad con las del período democrático previo. Las áreas geográficas cubiertas por estas organizaciones ahora incluyen con más frecuencia sectores comunitarios indígenas. El desarrollo organizacional previo se dio en las zonas de colonización, en el área de las propiedades fiscales reformadas y en zonas parcelarias no comunitarias, todas en sectores de valles bajos..$^{15}$ Sea por la residencia de muchos

de enajenabilidad limitada de la tierra) es la defensa de los recursos indígenas ante presiones del mercado. En tal caso, las demandas de agua para proyectos mineros y para consumo urbano se han resuelto a través de la explotación de napas subterráneas. En el segundo, la tierra andina tiene poco interés mercantil debido a su fertilidad limitada, restricciones climáticas, topografía montañosa, entre otras, por lo que tampoco existe presión interna. Pero en una región en extremo árida como ésta, la cuestión del agua es crítica para el desarrollo, así que los intereses externos no han tenido consecuencias de enajenación.

${ }^{14}$ Es el caso de Pampa Algodonal y Tres Cruces en la parte alta del valle de Azapa, una zona de parceleros aymara asignatarios de tierras de colonización durante la Reforma Agraria.

15 El núcleo fueron los valles de Lluta y Azapa, en menor medida el de Camarones y los oasis de la Pampa del Tamarugal y de Calama. 
de sus miembros, o por la naturaleza de sus intereses, las organizaciones supralocales son en la actualidad principalmente urbanas. Por ejemplo, muchos de los miembros de las organizaciones solicitantes de terrenos para colonizar el extremo norte de la Pampa del Tamarugal -iniciativa que se inaugura en 1988-, son aymara residentes en Arica e Iquique interesados en la posibilidad de obtener tierras posibles de explotar. Asimismo, una organización como Asoagro que reúne a los locatarios, mayoritariamente aymara, del terminal agropecuario de Arica, es eminentemente urbana (González 1991).

\section{Las organizaciones indígenas andinas urbanas}

Salvo aquellos que se encuentran en un proceso de descomunalización, de movilidad socioétnica, rompiendo sus relaciones con las localidades de origen, los emigrantes indígenas participan de una diversidad de grupos, algunos de los cuales se constituyen en organizaciones. Las prolongaciones, recreaciones y organizaciones urbanas de las comunidades andinas son una de las modalidades de manifestación de este fenómeno, siendo hoy las más importantes las prolongaciones urbanas de la acción de la propia organización comunitaria con base rural, los centros de hijos de pueblos, las cofradías religiosas y los clubes deportivos (González 1996a, 1996b). Cada tipo de organización tiene objetivos y atributos propios, que le otorgan fundamento y un perfil definido.

Las emigraciones modificaron el marco estrictamente rural de las comunidades creando migrantes que mantienen la condición de comuneros. Una fracción variable de sus miembros reside en la ciudad, y es frecuente que algunos ocupen cargos directivos. En esta medida, la organización de las comunidades es también, en algunos casos, un órgano de la comunidad translocal que tiene una fracción de sus miembros y desarrolla parte de sus operaciones en medios urbanos. A su vez, los centros de hijos de pueblos son organizaciones urbanas que reúnen en propósitos comunes a grupos de emigrantes provenientes de una misma localidad rural. Esta unidad de acción se estructura alrededor de objetivos sociales, culturales y económicos focalizados en la comunidad. La motivación principal es el deseo de desarrollo, entendido como "progreso" y "adelanto", de la comunidad rural de origen. Por su parte, las cofradías son organizaciones con motivaciones y objetivos precisos: celebrar a la
Virgen o al santo patrono de la localidad de origen a través del baile, pero también de oraciones y formas de actuación ritual, ceremonial y festiva que son propias de las celebraciones patronales en la localidad de origen. Muchos emigrantes acuden regularmente a las actividades que la advocación de los santos patronos de su localidad convoca, pero, en este caso, se prefiere hacerlo organizadamente en conjunto con otros residentes urbanos de la comunidad y con mayor implicación religiosa. Por último, los clubes deportivos son en realidad clubes de fútbol andinos en centros urbanos regionales. El fútbol es el deporte más practicado en Chile y su popularidad entre los indígenas andinos fue tempranamente alcanzada. Durante la década de 1980 se fundó en Arica la Liga Andina de Fútbol, compuesta actualmente por cerca de 24 clubes. Una análoga se creó luego en Iquique con auspicios de CONADI. Es también notable la red de clubes de fútbol de San Pedro de Atacama.

\section{La emergencia étnica y sus organizaciones en los Andes chilenos}

Un tipo de agrupación novedoso es el de las organizaciones étnico-reivindicativas. La innovación principal es que su marco sociológico de referencia no es ni la comunidad ni los intereses sectoriales, microrregionales o puramente económicos de otras formas de organización supralocal. Ahora se ha imaginado una "comunidad" (Anderson 1993 [1991]) étnica regional, se ha elaborado y adaptado una interpretación histórica y sociológica del pasado aymara, atacameño, coya y quechua en la zona, un aspecto de lo cual es la "invención de una tradición" (Hobsbawm 1983). Se han formulado y desarrollado demandas cuando el ambiente político de retorno a la democracia lo permitió, que pretenden interpretar las reivindicaciones de cada pueblo indígena regional. Estas demandas no tienen contenidos puramente desarrollistas o exclusivamente económicos. Introducen también planteamientos que tratan dimensiones culturales como la lengua, la cultura, el territorio y los recursos naturales. Surgen en tiempos relativamente recientes. En la zona aymara, el nacimiento de la primera de ellas, la Comunidad Cultural Aymara Pacha Aru, ocurrió en 1981 como iniciativa de estudiantes aymara de la Universidad de Tarapacá (Arica) reunidos en torno a actividades puntuales de promoción cultural. Solo a partir de 1986 paulatinamente cambia su orientación y surgen otras,

No $38 / 2009$

ESTUdiOS ATACAMEÑOS

Arqueología y Antropología Surandinas 
como el Centro Cultural Aymara (CCA), la Unión de Comunidades Aymara Aymar Markas, ambas en Iquique, y el Centro de Difusión Cultural Jacháa Marka Aru, creado por residentes aymara en Santiago. El perfil de sus miembros y dirigentes también es nuevo. Se trata de inmigrantes o hijos de ellos, con niveles educacionales comparativamente más altos, algunos profesionales, con experiencia urbana y facilidad para desenvolverse en relaciones institucionales y políticas. En un primer momento, al interior de medios universitarios y con organismos no gubernamentales locales $y$, posteriormente, con organizaciones indígenas mapuches, con partidos políticos de la coalición gobernante y con el propio gobierno de Aylwin, Frei y, más recientemente, de Lagos y Bachelet. Nos alejamos así del dirigente local o sectorial cuya capacidad de gestión alcanza a lo sumo el nivel municipal y sectorial (Gundermann y González 1996; Gundermann 2000).

En la zona atacameña no se da una emergencia equivalente debido a que, por una parte, una conciencia étnica comienza a instalarse más tarde que en el caso aymara (a fines de la década de 1980) y más explícitamente con las labores de promoción de organismos no gubernamentales en el contexto de una discusión sobre derechos étnicos y conocimiento de experiencias internacionales en curso. Por otra parte, no es un fenómeno urbano sino que está asociado a organizaciones de base (asociaciones de artesanos, comunidades eclesiásticas), y en especial, a algunos dirigentes. Estos son aquí más cercanos a los grupos rurales que representan $y$, en algunos casos, cuentan con calificaciones educacionales equivalentes, pero están lejos del perfil urbano y universitario de, por ejemplo, una organización como Pacha Aru de Arica. Además, una organización étnico-reivindicativa se conforma aquí más tardíamente y desde bases comunitarias bajo la figura del Consejo de Pueblos Atacameños, luego que se formaran las comunidades indígenas atacameñas que lo integran. Surge para realizar una interlocución y demanda más articulada hacia la agencia estatal encargada de la política indígena, los municipios de la provincia de El Loa, las autoridades regionales y las principales empresas mineras de la zona. Mucho más tarde, a finales de la década de 1990, surge una organización (Zahli Lickan Kcappur) similar a las que se crearon en la zona aymara 15 años antes, ahora en reacción al Consejo, al que consideran oficialista e ineficaz. En esta medida, no es ajena al escenario creado por la política indígena en la región.

Los quechua y coya no han desarrollado este tipo de organizaciones. Su dinámica es diferente de la atacameña por dos razones: 1) Su etnificación y organización con sentido étnico es tardía y deriva de la política impulsada con la Ley Indígena; 2) Este mismo cuerpo legal provee personerías jurídicas para formalizar las iniciativas de organización que se realizan a partir de grupos locales y parentales, tomando la de comunidad indígena cuando se lleva a efecto desde bases rurales y la de asociación indígena cuando esa unidad de origen no existe, es más difusa o indemostrable. Para estos grupos no ha sido necesaria la creación de asociaciones u organismos de coordinación más amplios, lo cual queda subrogado por la acción de la CONADI. Tampoco existen condiciones por la dispersión espacial y de intereses, así como por competencias y conflictos internos.

\section{Desarrollos, alianzas e innovación}

Las organizaciones descritas alcanzaron notoriedad cuando se incorporan al movimiento indígena histórico del país. Hasta hace unas décadas se restringía al de los mapuche del centro sur de Chile, en recomposición luego de una largo repliegue durante la dictadura. ${ }^{16} \mathrm{La}$ apertura hacia los problemas indígenas nacionales llevó a que entre sus filas surgieran los delegados ante la Comisión Especial de Pueblos Indígenas (CEPI), formada a inicios de la década de 1990 por el gobierno de Aylwin como resultado de un compromiso establecido previamente entre la Concertación de Partidos por la Democracia y las organizaciones indígenas del país. Esos mismos representantes mediarán, ahora desde cargos burocráticos de la CONADI, sucesora de la Comisión Especial ${ }^{17}$, buena parte de las relaciones entre las organizaciones aymara y atacameñas y el Estado. El control ejercido por estos funcionarios ayuda a explicar que, con la excepción de dos de ellas (Pacha Aru y Aymar Marka), las organizaciones étnico-reivindicativas hayan desapa-

\footnotetext{
${ }^{16}$ Además de los aymara se incorporaron otras dos pequeñas etnias en un conjunto relacionado de movimientos étnicos: una andina, la de los atacameños de la región de Antofagasta; y una polinésica, la de los rapanui de Isla de Pascua. Como se ha dicho, la emergencia quechua y coya es más tardía.

17 Según la Ley 19253 de 1993, también llamada Ley Indígena.
} 
recido de escena, manteniendo una existencia virtual (Gundermann 2000).

Estas entidades crearon algunos organismos técnicoprofesionales con membresía exclusiva o principal aymara, como una manera de captar fondos provenientes de la cooperación internacional, y más tarde, para actuar como organismos ejecutores de proyectos y consultorías financiadas por la CONADI. Igualmente compuestas por técnicos y profesionales aymara, otras surgieron a partir de 1993 sin una vinculación directa con las organizaciones étnico-reivindicativas. Al igual que las de representación étnica, constituyen entidades que innovan completamente el panorama organizativo andino y que no pueden explicarse sino con base en el proceso de emergencia étnica. No se presenta en la zona atacameña una derivación equivalente, aun cuando desde los municipios de San Pedro de Atacama y Ollagüe se ha buscado privilegiar a individuos indígenas para cargos en la administración y en algunos tipos de consultoría. De hecho, la alcaldesa de San Pedro, varias veces reelecta, suele destacar la alta proporción de indígenas y de mujeres de la planta municipal. ${ }^{18}$

Varias alianzas e intentos federativos se dieron durante el régimen autoritario. Entre aquellas con orientación campesina registramos en 1987 la alianza entre dos organizaciones de ganaderos del altiplano norte, una de artesanas urbanas de Arica y otra étnico-reivindicativa, cuya convergencia se dio por el interés de sus dirigentes más que por afinidad de objetivos. Esta alianza se disolvió ante divergencias de los dirigentes que la promovieron. Esas organizaciones rurales entraron luego en una fase de inactividad que las llevó a desaparecer. Debido al inmovilismo de las agrupaciones amplias, se desarrollaron entre esos ganaderos varias asociaciones gremiales loca-

18 Las mujeres aymara tienen una participación limitada en las asambleas y organizaciones; los hombres adultos de sus hogares son los que están presentes en este tipo de espacios públicos. De esta manera, las únicas agrupaciones de mujeres aymara son aquellas representadas por los Centros de Madres (CEMA), en franca desaparición, y los grupos artesanales. Vistas a largo plazo, representan una innovación en la organización indígena no exenta de contradicciones. Los estímulos externos explican la emergencia y permanencia de uno y otro tipo de organización. En sentido contrario, destaca entre los atacameños la alta participación de mujeres en organizaciones y dirigencias, lo que se explica por la extensiva proletarización masculina en la minería, turismo y rubros relacionados. les, estructuradas por grupos de pequeñas comunidades sucesoriales vecinas y afines. ${ }^{19}$ Otro caso destacado es el de la coordinación de seis organizaciones agrupadas en la iniciativa de colonizar la Pampa del Tamarugal, compuestas principalmente por aymara, la mayoría con residencia en Arica. Las que surgieron en Iquique con el mismo propósito desaparecieron a poco andar. Por presión de funcionarios estatales se creó en 1992 una corporación de derecho privado, la que luego de un período de crisis se reorganizó en 1996, y con metas más modestas siguió operando tras sus objetivos iniciales.

Las organizaciones étnico-reivindicativas protagonizaron a finales de la década de 1980 la mayoría de los intentos de alianza y federación entre organizaciones. La Coordinadora de Organizaciones Aymara surge en 1987, pero la tensión entre dirigentes de dos de sus grupos integrantes terminó con ella a fines de esa década. La Federación Andina Ayni, a su vez, se crea en 1988 buscando alcanzar una cobertura regional, aunque luego terminó por reordenarse a escala provincial manteniendo una coordinación fluida entre dos provincias. En la década de 1990 desaparece con el paso de los dirigentes que las impulsaron a la arena político partidaria de la Concertación y a la burocracia estatal. Una nota característica de tales intentos es su lógica de dicotomización y oposición (a organismos no gubernamentales, a otras organizaciones y dirigentes, a la agrupación de organizaciones de otra provincia). El carácter efímero de prácticamente todas ellas, así como las dinámicas de liderazgo que les son propias, señala el fuerte impacto de las facciones y las personalidades individuales en el devenir del movimiento aymara. Un marcado contraste presentan las comunidades atacameñas del Salar de Atacama y Loa Superior, que mantienen una persistente alianza que da origen a una relativamente exitosa asociación de comunidades dotada de legitimidad y con capacidad de ejercer una fluida relación con el Estado y las empresas mineras de la región de

19 En 1995, cinco de ellas, correspondientes al municipio de General Lagos, dieron origen a Suma Alpaca, una federación de asociaciones gremiales locales de criadores de llamas y alpacas. Paralelamente, en reacción a la iniciativa anterior, se forma a mediados de ese año la Asociación Indígena de Ganaderos Aymara del Altiplano compuesta de miembros de siete sectores de comunidades sucesoriales de los municipios de General Lagos y Putre. En este caso, las membresías fueron individuales, aunque intentaban recuperar las localidades mediante comités. 
Antofagasta. Visto en perspectiva, constituyen una excepción (González 1991; Gundermann y González 1996).

La puesta en práctica de la política indígena de los gobiernos de la Concertación condujo a la definición de grupos y organizaciones. A tono con los formalismos con que se revisten esas relaciones, en particular en lo que atañe a la transferencia de recursos, se consideró necesario crear figuras jurídicas específicas para la condición de "originario". Con la Ley Indígena de 1993 surgen entonces la "comunidad" y la "asociación" indígena. Rápidamente proliferan en la zona altoandina aymara y en Atacama, a veces por propia iniciativa de los grupos locales que acuden a la fórmula de comunidad y de grupos de interés que lo hacen con la de asociación. No obstante, en extensas zonas de valles y precordillera de Tarapacá, Arica y Parinacota, el impulso principal provino de la CONADI, la agencia estatal creada por la misma ley. El apoyo financiero a las iniciativas locales se asoció con, y frecuentemente se condicionó a, la formación de comunidades y asociaciones. Pasados algunos años, la mayoría de los grupos andinos de base local se habían constituido en comunidad y muchos grupos urbanos de origen más misceláneo en asociación indígena. Los organismos que ejecutan la política indígena, como la CONADI y el Programa Orígenes, siguen canalizando su acción con ellas y ejercen presiones para su formación. Más ampliamente considerada, la mayor acción pública hacia los pueblos originarios ha tenido por consecuencia el privilegio de las comunidades indígenas como figura organizativa en la comunicación y las relaciones con el Estado.

Desde inicios de la década de 1980 los gobiernos municipales se han fortalecido con medidas de desconcentración de funciones y un correlativo aumento de prerrogativas y recursos. Ellos se relacionan con organizaciones de base territorial y funcional, especialmente juntas de vecinos. En comunas exclusivamente indígenas, comunidad indígena y junta de vecinos suelen superponerse, pero ésta no es la situación en todos los municipios andinos. Por lo demás, a las organizaciones indígenas se las relaciona con la política indígena de la Concertación, a cargo de agencias estatales también controladas por funcionarios afines a ella. Para los gobiernos locales controlados por autoridades opositoras, ello ha conducido al reforzamiento de la acción municipal hacia las juntas de vecinos y otras organizaciones, con el fin de mantener su autonomía y sostener redes de relaciones políticas locales. Alternativamente, se intenta ganar influencia en las comunidades indígenas a través de posicionar dirigentes aliados o proclives, y de la asignación de inversiones.

A este panorama se suman ahora las organizaciones definidas por criterios étnicos promovidas por la política indígena, y a la vez, con la desconcentración político administrativa que fortalece a los municipios se refuerza la importancia de las juntas de vecinos. Otros tipos de organización mantienen su vigencia y dinamismo (autónomas, como las comunidades sociológicas translocalizadas, los grupos religiosos o los clubes deportivos), en tanto que algunas se encaminan a desaparecer o a permanecer inactivas (en general, las formas de organización promovidas desde las agencias estatales como los centros de madres, las asociaciones gremiales o los comités ad hoc a algún programa público). Podría decirse entonces, que junto a una fundamental dependencia del Estado, la organización andina también logra mantener un ámbito de gestión asociativa formal autónoma, apoyada en una cultura comunitaria todavía vigente.

\section{* Una tipología de organizaciones ANDINAS EN EL NORTE DE CHILE}

El panorama organizativo andino se puede ordenar de acuerdo a la presencia de manifestaciones local comunitarias, o bien, supralocales (en el sentido que no tienen como referente principal a la comunidad rural, ya sea real o evocada, sino que a otras colectividades cuyos límites van más allá de lo local-comunitario). Examinando la variedad y frecuencia de formas en que la organización andina está referida o no a lo local tendremos buenos elementos de juicio para valorar a las comunidades sociológicas como una base de la organización andina. La relación o independencia con el Estado es también una dimensión importante para evaluar la autonomía o dependencia de la organización indígena de esta zona con las agencias estatales. En relación con lo anterior, se puede constatar la vigencia de organizaciones que siguen lineamientos étnicos en desarrollo durante las últimas dos décadas, y la manera en que ello se distribuye en la variedad organizativa existente. 
Los Cuadros 1 y 2 presentan las distintas manifestaciones organizativas andinas según su condición local o supralocal, y según las orientaciones de la acción colectiva. Aparecen núcleos que persiguen propósitos y dan curso a actividades de gestión y autogestión económica. Otras, en cambio, son instancias de representación de intereses ante las agencias del Estado, otras entidades andinas y la sociedad civil. Unas tantas más apuntan al desarrollo de relaciones de sociabilidad comunitaria y étnica. Están también aquellas que se dirigen al fomento de actividades culturales. Entre las supralocales encontramos organizaciones que establecen demandas étnico-reivindicativas y otras que prestan algunos servicios profesionales, las que pueden también servir como plataformas para el despegue político de algunos individuos. Se tiene por último, a la comunidad andina de naturaleza polifuncional, de base local pero translocalizada, en tanto un segmento de sus miembros mantiene una localización residencial dispersa en el espacio regional. Su acción se orienta casi siempre a gestionar o representar a la localidad de origen $y$, en tal caso, es coherente situarla como un tipo de organización local basal o primario.

Respecto de la comunidad, recordemos la existencia de dos variantes, sucesorial y local de la zona de valles, y sus funciones de administración, defensa e identidad. Como propiedades de importancia para que las comunidades funcionen como soporte o componente de otros atributos y formas organizativas, destacamos la masividad de su distribución y la dispersión de sus miembros. La comunidad es también una organización económica dirigida a administrar en beneficio de los hogares miembros, un patrimonio colectivo, o como mínimo, recursos no colectivos cuyo uso requiere ser coordinado.

La representación de intereses y demandas ante el Estado por parte de grupos, colectividades y organizaciones provistas de personería jurídica es más una consecuencia de la acción del Estado que de algún espíritu formal-legalista especial de los pueblos andinos. Tanto para comunidades, como para entidades más amplias, dotarse de la condición jurídica de junta de vecinos, asociación gremial, comunidad indígena, $u$ otras eventualmente creadas para cumplir otros objetivos, sirve también para fines de representación. En la experiencia de la organización andina esta formalización ha sido un requisito para la relación con los organismos estatales, puesto que para los burócratas, los sujetos colectivos andinos, y populares en general, son tales únicamente en la medida que puedan hacer manifiestas las certificaciones formales de rigor.

La proliferación de organizaciones de representación en todos aquellos puntos sensibles de articulación entre sujetos andinos y Estado obedece entonces solo parcialmente, a la necesidad interna de asegurar el compromiso de sus miembros individuales y consagrar la actividad de sus dirigentes. Está presente a todo lo largo de la historia de las relaciones entre los organismos estatales y los sectores campesinos y populares urbanos regionales. Hasta inicios de los 60 más relacionada con la promoción popular, con la dictadura se transforma en uno de los puntos terminales de la canalización de prestaciones, la recepción de demandas y el control político de los sectores populares. Con el retorno a la democracia el vínculo burocrático ha mantenido ese perfil, aunque los rasgos autoritarios y de control han dado paso a formas relativamente más flexibles de relación.

Al igual que con los objetivos de gestión económica o los de representación colectiva, las materias culturales pueden ser el eje de definición de una organización, pero también un componente o atributo. La comunidad local es, entre otras cosas, una organización ritual. De manera menos formal que antaño (si pensamos en la tradición ritual del catolicismo andino) o, en el otro extremo, de una manera fuertemente estructurada y compulsiva (si nos atenemos a los grupos rurales protestantes, con frecuencia reunidos según una base local), la actividad religiosa andina es una dimensión relevante desde la cual se desarrolla organización. Normalmente confundidas con las actividades comunitarias, en comunidades de valles encontramos organizaciones como las cofradías religiosas. Esta condición de órgano de la comunidad provisto de un perfil propio es todavía más acentuada en las cofradías y los bailes religiosos formados por emigrantes. Lo religioso se encuentra en estos medios sociales también organizado más allá de la comunidad cuando, por ejemplo, se coordinan bailes religiosos de carnavales que se originan en la aglutinación de individuos pertenecientes a las mismas comunidades de origen; o bien, definitivamente prescindiendo de éstas, como es el caso de una organización de bailes religiosos de Arica. Este ir más allá de la comunidad también puede adquirir otro sentido: ya no es solo la reproducción religiosa y social

$\mathrm{N}^{\circ} 38 / 2009$

ESTUdios ATACAMEÑOS

Arqueología y Antropología Surandinas 


\begin{tabular}{|c|c|c|}
\hline $\begin{array}{c}\text { Tipo de } \\
\text { organización }\end{array}$ & Subtipo & Situaciones vigentes \\
\hline $\begin{array}{l}\text { Comunidad } \\
\text { translocalizada }\end{array}$ & $\begin{array}{l}\text { Comunidad sucesorial } \\
\text { altoandina } \\
\text { Comunidad local de valles } \\
\text { y oasis }\end{array}$ & $\begin{array}{l}\text { Estancias de la zona altoandina aymara. } \\
\text { - Comunidades de oasis y valles altos, medios y bajos correspondientes con el espacio andino } \\
\text { histórico aymara y atacameño. }\end{array}$ \\
\hline Económica & $\begin{array}{l}\cdot \text { Producción agropecuaria } \\
\cdot \text { Comercialización } \\
\cdot \text { Mixtas }\end{array}$ & $\begin{array}{l}\text { - Comunidades y segmentos de comunidades administradoras de sistemas locales de riego; } \\
\text { también las que emprenden proyectos de desarrollo de infraestructura para la producción. } \\
\text { - Comunidades locales que abordan iniciativas coordinadas de comercialización. } \\
\text { - Comunidades locales polifuncionales que emprenden proyectos económicos diversificados. }\end{array}$ \\
\hline Representación & $\begin{array}{l}\text { Territoriales } \\
\cdot \text { Comunitarias }\end{array}$ & $\begin{array}{l}\text { - Juntas de vecinos, comités vecinales y centros de madres comunales. } \\
\text { - Asociaciones gremiales locales, comunidad indígena y asociación indígena de la Ley 19.253. }\end{array}$ \\
\hline Sociales & $\begin{array}{l}\text { Clubes deportivos rurales } \\
\text { Clubes deportivos andinos } \\
\text { urbanos } \\
\text { Centros de hijos de } \\
\text { pueblos }\end{array}$ & $\begin{array}{l}\text { Clubes de fútbol organizados normalmente por localidades. } \\
\text { Clubes de fútbol compuestos idealmente, por miembros de una localidad de origen. } \\
\text { - Núcleos organizados de migrantes provenientes de comunidades locales de oasis y valles. }\end{array}$ \\
\hline Culturales & $\begin{array}{l}\text { - Organizaciones religiosas } \\
\text { locales } \\
\text { - Bailes de carnavales } \\
\text { - Cofradías locales } \\
\text { - Conjuntos folclóricos }\end{array}$ & $\begin{array}{l}\text { - Organización religiosa interna de la comunidad local (sistema de cargos, iglesia protestante } \\
\text { local, etc.), actualmente con grados diversos de vigencia. } \\
\text { - Grupos organizados por localidades de origen para la celebración de carnavales. } \\
\text { - Grupos organizados por localidad de origen para la celebración de fiestas religiosas } \\
\text { patronales. } \\
\text { - Grupos organizados con base en comunidades para la representación de lo aymara, lo } \\
\text { atacameño o "lo andino" (música, bailes, coreografías rituales, etc.). }\end{array}$ \\
\hline
\end{tabular}

Cuadro 1. Formas organizacionales aymara y atacameñas locales y sus atributos en el norte de Chile. Fuente: González (1991,1996b), e información etnográfica de los autores.

\begin{tabular}{|c|c|c|}
\hline $\begin{array}{l}\text { Tipo de } \\
\text { organización }\end{array}$ & Subtipo & Situaciones vigentes \\
\hline Representación & - Sectoriales en general & $\begin{array}{l}\text { - Juntas de vecinos que integran miembros de varias localidades. } \\
\text { - Uniones comunales de juntas de vecinos. } \\
\text { - Asociaciones gremiales de productores rurales, poco activos en el presente. } \\
\text { - Asociaciones gremiales urbanas con participación indígena variable, en declinación o inactivas. }\end{array}$ \\
\hline Económicas & $\begin{array}{l}\text { Producción y } \\
\text { comercialización }\end{array}$ & $\begin{array}{l}\text { - Sociedades civiles administradoras de riego (Alto Azapa). } \\
\text { - Componente tecnoproductivo y de mercado de cooperativas agrícolas y campesinas. } \\
\text { - Sociedades de responsabilidad limitada con objetivos productivos y de comercialización. } \\
\text { - Asociaciones gremiales de productores andinos que desarrollan acciones productivas y de } \\
\text { comercialización. }\end{array}$ \\
\hline Culturales & $\begin{array}{l}\text { - Bailes religiosos } \\
\text { - Asociación de bailes }\end{array}$ & $\begin{array}{l}\text { - Bailes religiosos no organizados según membresías locales. } \\
\text { - Organización de bailes religiosos y cofradías organizados con base en localidades de nacimiento } \\
\text { u otro criterio de incorporación. }\end{array}$ \\
\hline \multicolumn{2}{|c|}{ Etnico-reivindicativas } & $\begin{array}{l}\text { Organizaciones aymara y atacameñas, usualmente urbanas, que plantean demandas étnicas } \\
\text { agregadas. } \\
\text { Consejo Nacional Aymara. } \\
\text { Consejo de Pueblos Atacameños. }\end{array}$ \\
\hline \multicolumn{2}{|c|}{ Organismos no gubernamentales } & $\begin{array}{l}\text { - Organizaciones de profesionales y técnicos indígenas con asiento urbano, especializadas en la } \\
\text { prestación de servicios profesionales a la población andina. }\end{array}$ \\
\hline
\end{tabular}

Cuadro 2. Formas organizacionales andinas supralocales y sus atributos en el norte de Chile. Fuente: González (1991, 1996b), e información etnográfica de los autores. 
de la comunidad lo que está en juego, sino la representación de la comunidad en búsqueda de reconocimiento y legitimidad en contextos sociales urbanos o periurbanos, más complejos y agresivos.

Con un carácter urbano y sin relación directa con las comunidades, las asociaciones étnico-reivindicativas y los organismos no gubernamentales que siguen esta misma línea son, en el campo de las formas organizacionales andinas, un resultado contemporáneo de la reorganización espacial y social de la últimas décadas, así como de cambios internos y de la relación política con la sociedad y el Estado nacional. Pueden analizarse como puntos de desarrollo avanzado de tendencias de cambio más generales en la sociedad andina.

\section{* Dinámica de las organizaciones INDÍGENAS ANDINAS}

La demanda estatal de interlocutores organizados ha tenido como consecuencia la proliferación de organizaciones y su diferenciación en las de tipo local y supralocal, nivel este último, que no existía tradicionalmente. Allí donde encontrábamos solo a la comunidad, en medio siglo ha ido surgiendo una diversidad de comités, asociaciones, juntas, centros, cooperativas y sociedades. Muchas se mantuvieron dentro de la cobertura ofrecida por los grupos locales tradicionales, otras innovaron y cubrieron radios más extensos. Esas coberturas pudieron mantenerse con membrecías ordenadas según adscripciones locales, o bien, de acuerdo a los cambios sociológicos que sacudían la sociedad andina, resultar de adscripciones individualmente inscritas.

Otro de los resultados, en un sentido inverso de la tendencia anterior, es la sobreposición o saturación de formas organizativas sobre la comunidad local. La formulación de los diseños de política popular, incluida la definición de los formatos organizativos más apropiados a su aplicación, sigue lógicas centralistas características de la historia política nacional. El referente más inmediato para su puesta en práctica ${ }^{20}$ en la zona andina fue y es la

\footnotetext{
${ }^{20}$ Tipificada de desarrollismo en la década de 1950, de promoción popular en la de 1960, de control autoritario durante la dictadura y de participacionismo con la Concertación.
}

comunidad local, que lejos de ser una formación colectiva estable con legitimidad y autoridad, ha sido sistemáticamente utilizada como plataforma para la proposición e imposición de formas organizacionales ad hoc con políticas y programas y no es, por lo tanto reconocida. De la ceguera, rigidez, centralismo y autoritarismo de la razón tecnocrática instalada en el Estado han derivado problemas de coordinación, fragmentación de intereses, surgimiento de tensiones internas originadas en esta proliferación, aprovechamiento de la oferta organizacional por facciones disidentes y liderazgos emergentes. Las figuras jurídicas de la comunidad y asociación indígena no han remediado esta dinámica que fue uno de sus propósitos. En vez de dar mayor coherencia a la organización indígena de base en su relación con el Estado, han favorecido la proliferación y las tendencias faccionalistas internas.

Los Cuadros 1 y 2 evidencian la heterogeneidad y complejidad organizacional andina. Desde el punto de vista de las funciones, objetivos y formas de acción, la variedad existente resulta notable. Algunas condensan funciones, son entidades polifuncionales. Se da en ellas una situación de convergencia, en el sentido de que incorporan en una misma unidad social diversas funciones, objetivos y metas. El ejemplo más adecuado es, sin duda, el de la comunidad andina de base. Una comunidad local agrícola a través de su organización a un tiempo administra un patrimonio y representa sus intereses ante las autoridades de turno, y lo hace apoyándose en su condición de comunidad de propietarios, o como organización territorial de junta de vecinos. Con frecuencia mantiene en su seno segmentos religiosos, un centro de hijos en un medio urbano, un club de fútbol, etc. En otras, por el contrario, se aprecian fenómenos de desagregación o diferenciación, cuando ciertas funciones son materia de acciones desplegadas según marcos organizativos, definiciones y grupos distintos. Estos órganos pueden tener una vigencia espacialmente desagregada. Formas organizativas que en un primer momento asumen funciones relacionadas con la comunidad, pueden más tarde independizarse y adquirir vida propia. Mientras se mantenga en relación con la comunidad de origen nos movemos en el marco de las comunidades translocales. Cuando la autonomía ha tenido lugar, sea por procesos internos o inducción externa, las formas de organización supralocal adquieren existencia. 
Propiedades tales como la de orientarse según objetivos económicos, sociales, culturales o de representación están presentes en las organizaciones locales y supralocales. Los Cuadros 1 y 2 señalan la profusión de manifestaciones organizativas, las variantes, las convergencias y sus múltiples traslapes formales, institucionales y funcionales; resalta el abanico de tipos y subtipos, unidades sociales y niveles de agregación en que operan. El hecho básico a destacar es la superposición sobre la comunidad local de prácticamente todas las formas organizativas presentadas, y al mismo tiempo, la diferenciación en distintos órganos externos a la comunidad que rompen con la localidad andina como punto de anclaje. En perspectiva histórica, tales desarrollos se producen en las últimas décadas y surgen de la relación que la población andina establece con el Estado que intensifica su presencia en la zona andina con fines desarrollistas, geopolíticos o asistenciales, y que presiona e impone sobre las comunidades formatos organizativos coherentes con la implementación de programas.

A partir de entonces surgen tensiones entre las agrupaciones locales y supralocales. Por una parte, estímulos principalmente externos impulsan a la formación de entidades amplias que pueden cumplir funciones de representación ante el Estado, pero también coordinar acciones a mayor escala, más eficientes colectivamente que en un plano puramente comunitario o familiar. De esta manera, las organizaciones amplias prometen el acceso a bienes y servicios a través de la agregación de esfuerzos y recursos o por medio de la legalidad que proporcionan. Por otra parte, la localidad rural es un espacio particularmente denso de relaciones económicas, sociales y simbólicas que sigue mediando la reproducción social de los individuos y de las unidades familiares. En un grado seguramente menos intenso y más diverso que en el pasado, la vida de los individuos y hogares andinos, sea en aspectos internos o en los nexos con contextos más amplios (microrregiones, centros urbanos, región), se sigue desarrollando con el concurso de la comunidad. Espacio de identidad, de un "nosotros" materializado en la cotidianeidad de las relaciones primarias, de defensa y refugio, de solidaridad y apoyo, constituye la base de repliegue para los individuos y hogares cuando la participación en grupos y organizaciones mayores se torna crítica. La relación entre la organización local y supralocal es, según esta mirada, una relación dinámica, cambiante y, con frecuencia, habitada por competencias o disputas.

Sin embargo, la oscilación cíclica entre participación local y supralocal no es el único aspecto dinámico. En la organización de los bailes religiosos que participan de la celebración de la Virgen de las Peñas (un santuario religioso católico popular con alcance a toda la provincia de Arica), hasta hace algunos años atrás, solo cinco de 38 bailes provenían de una misma localidad andina de origen. En los restantes, la procedencia de sus miembros es multilocal, y entre ellos hay un número significativo de no aymara. Hay indicios de que en el pasado el número de grupos locales fue mayor. Lo que tenemos ahora es una transición, al parecer irreversible, de una participación religiosa por grupos comunales a otra en que éstos desaparecen. Se trata de un santuario que tuvo un origen local, pero que con el tiempo llegó a constituirse en uno provincial; ya no es una advocación comunitaria cuya congregación de fieles tenga por límites máximos los grupos y redes parentales de la comunidad. Estamos ahora ante una comunidad distinta, más general e impersonal que se objetiva no cotidianamente - salvo quizá las cofradías y su organización, con un nivel de actividad mayor a lo largo del año-, sino solo durante el tiempo conmemorativo. La identidad asociada a esta congregación mayor ya no es local, es un tipo de identidad religiosa con alcances provinciales, más amplios y anónimos. No existe en este caso la posibilidad de un retorno cíclico a lo local, produciéndose una evolución desde una realidad local comunitaria aymara a otra en la cual ésta deja de existir como piso o infraestructura social de tales actos religiosos.

En este sentido, las organizaciones étnico-reivindicativas aymara y atacameñas de mediados de la década de 1980 en adelante son comparables con el caso referido. Su sentido proviene de la referencia a una comunidad étnica y su etnodesarrollo, adoptando el papel de agente de movilización y presión ante el Estado. Sus miembros poseen círculos de parientes con los que se relacionan y que residen indistintamente en el campo y en la ciudad, parte de los cuales corresponden con comunidades a las que pertenecen por nacimiento. Pero, además se incorporan electivamente a estas otras organizaciones andinas cuya comunidad de referencia, ahora étnica, es cualitativamente distinta. 
Encontramos historias organizativas en cierta medida similares en otras agrupaciones andinas, como las de artesanas, las asociaciones gremiales urbanas de pequeños comerciantes o de transportistas, en las que la membresía es individual, sin referencia o con una implicación débil de comunidades. Entre sus miembros y la asociación mayor no median entidades menores definidas por la localidad de origen, sino una relación individual directa. Advertimos entonces una redefinición de la relación entre el individuo y la organización comunitaria. En el pasado, la pertenencia a una agrupación fue sinónimo de adscripción a una comunidad en distintos niveles o planos: linaje, sucesión, localidad, pueblo indígena histórico. En el presente, la pertenencia a organizaciones puede ser muy variada, al igual que los grupos de referencia (locales, pero también gremiales, residenciales, religiosos, étnicos o políticos). Los asociados no dejan de pertenecer a comunidades, pero estas no inciden directamente en el destino de la asociación más amplia. Son agrupaciones en que se participa de manera paralela y que casi no se interpenetran. Así, el nexo entre organizaciones comunales y supralocales es de ampliación de la variedad y cantidad de agrupaciones, más que de reemplazo. La organización de base local no está viviendo un proceso de retroceso paulatino que la conduzca a su desaparición, sino más bien, un enriquecimiento e incremento de su complejidad. La ruptura con los moldes rurales tradicionales se ha traducido en transformación y reintegración y no en descomposición. Un grado de diferenciación funcional e institucional se aprecia hoy en una sociedad andina que participa de procesos de modernización regionales.

¿Qué relación guardan la configuración y tendencias de organización andinas reseñadas con la explosión étnica de los últimos años? Las comunidades indígenas tienen en todos los casos andinos una relación con comunidades rurales rastreables históricamente y existentes en la actualidad, como lo exige, además, la propia legislación. De esa forma, pareciera que dicha comunidad confirma y legitima una realidad sociológica con raíces históricas. En la medida en que se acude a la tradición como fuente de legitimación, hay un proceso de retorno a ella y un distanciamiento de las tendencias de transformación que hemos analizado ¿Hasta qué punto es así? Primero, la propia Ley Indígena consagra la figura de la asociación indígena asumiendo que no toda la realidad sociológica indígena del país se resuelve en los términos de las comunidades rurales históricas, la andina quizás menos que ninguna. Segundo, la forma de adscripción a la comunidad indígena es, en última instancia, individual. Por diferentes razones, las comunidades legalmente constituidas han excluido a algunos individuos o grupos. Una causa es la voluntad de hacerse miembro o no hacerlo por parte de individuos y hogares; otra es el extendido fraccionalismo y disidencia que recorre las comunidades sociológicas. Tercero y derivado de lo anterior, con cierta frecuencia una comunidad sociológica contiene dos o más comunidades jurídicas, situación que responde al fraccionalismo y conflictos internos que nunca faltan en los pueblos andinos. La comunidad indígena es entonces, bastante distinta de las comunidades sociológicas y de la comunidad tradicional de antaño. Se apoya en una cultura comunitaria y en representaciones de la continuidad tradicional, pero responde a condiciones presentes.

En efecto, la tradición, o más bien, el espectro de la tradición no deja de hacerse presente. Así lo atestigua la creación y expansión generalizada de las comunidades y asociaciones indígenas durante los últimos 15 años. Llevan el nombre de la tradición y la invocan ante el Estado, pero para constituirse con base en adscripciones personales, o grupales exclusivas. Paradójicamente, puede considerarse uno de los tipos de organización más altamente dependiente de las relaciones con las agencias públicas, en especial las encargadas de implementar la política indígena. Tanto lo es que muchas se conformaron motivadas principalmente por acceder a recursos estatales. Otras caen en inactividad cuando los requerimientos de recursos no han tenido éxito o han mermado, o cuando el desencanto ha cundido por los magros resultados alcanzados. Como sea, representó un medio bastante eficiente de acercar recursos a los indígenas, de dar a conocer los elementos caracterizadores de la política indígena donde no se conocían, y construir una nueva representación de lo indígena (idea de pueblo originario, derechos colectivos de minorías e indígenas, territorialidad y cultura, etnodesarrollo, reconocimiento colectivo, etc.).

Si la comunidad indígena es una entidad integrante de una totalidad más amplia que da origen a un pueblo originario, y si la propia política indígena así lo recalca, entonces la comunidad rural o alguno de sus segmen-

$\mathrm{N}^{\circ} 38 / 2009$

ESTUDiOs ATACAMEÑOS

Arqueología y Antropología Surandinas 
tos aparecen naturalmente relacionados con órganos de representación supralocales. Estos son el Consejo de Pueblos Atacameños y el Consejo Nacional Aymara. Y la política indígena así lo entiende cuando en demanda de un consejero nacional organiza elecciones competitivas que, en los hechos, resuelven los votos de los miembros de comunidades y asociaciones indígenas legalmente constituidas. O la definición de un cuerpo de consejeros aymara a través de su elección por las comunidades de cada municipio de la región de Tarapacá y Arica-Parinacota. Estas entidades representan a las agencias públicas la demanda de desarrollo local (que atañe directamente a los grupos de base), pero sobre todo una demanda étnica, más allá de las circunstancias particulares de cada grupo. Con todo, resulta un conjunto de niveles coherente y relacionado que no carece de fricciones y fracturas. Se reproduce entonces la articulación tensionada entre lo local y lo supralocal, ahora en clave étnica. Entre los aymara han habido recurrentes objeciones acerca de la legitimidad de representantes y consejeros, en parte sustentadas por los procedimientos y manejo de las elecciones, en parte por el desarrollo de una división entre Arica y Parinacota respecto de Iquique, y en parte por el origen urbano de los consejeros y su eventual lejanía de los intereses rurales, agrarios y campesinos locales. En el mismo sentido se cuestiona también la prioridad y validez de las demandas y la orientación de la interlocución, en la medida que desde la base se da más importancia a lo particular por sobre lo general.

A lo anterior se suma que, a medida que la identificación étnica se expande y que la acción estatal progresivamente se etnifica ${ }^{21}$, la cuestión étnica adquiere un valor político mayor en la arena municipal. Progresivamente se suman actores sociales y políticos locales interesados en valores políticos redituables, como las relaciones y apoyo con el gobierno comunal y las agencias estatales con presencia en la comuna, aunque también por los valores económicos asociados (p.e., prestaciones estatales, inversiones y subsidios) y el poder de control para su asignación y distribución. Con el concurso de alcaldes, concejales, agentes políticos locales y dirigentes, una política local etnificada se ha ido gestando en el espacio

\footnotetext{
${ }^{21}$ Como consecuencia de las actividades de la CONADI, el Programa Orígenes, los mandatos de coordinación interagencias para un desempeño coherente y coordinado hacia los indígenas, etc.
}

local. Para los alcaldes resulta de interés ganar influencia sobre los presidentes de comunidad indígena, representantes comunales ante el Consejo Nacional Aymara. En el mismo sentido lo es para la alcaldesa de San Pedro de Atacama obtener adhesión y una buena interlocución con los presidentes de las comunidades indígenas atacameñas de su comuna, integrantes del Consejo de Pueblos Atacameños.

\section{$\leftrightarrow$ Conclusiones}

Es común observar la participación andina en grupos y organizaciones de distinta índole y orientación, rurales, urbanas o rural-urbanas. La acción colectiva indígena andina es nutrida y dinámica, lo que lleva a que existan numerosas organizaciones en todas las comunas y centros urbanos regionales. Las tasas de participación aymara y atacameña en organizaciones duplican y hasta triplican las de la restante población regional. Los indígenas andinos no han dejado de actuar asociativamente a pesar de los cambios sociales, migraciones y movilidad. Las organizaciones sí se han diversificado mucho en comparación con el pasado. No podría esperarse que el impulso de proliferación se atenga exclusivamente a formatos locales, de modo que en las condiciones modernas otros diseños con otros alcances han aparecido.

Ya no se trata de la organización comunitaria de origen colonial. Permanecen solo trazas de las instituciones de la organización tradicional. Reemplaza a la comunidad histórica un nuevo sistema de agrupaciones que incorpora varios atributos: 1) Hoy consiste de una pluralidad de grupos y organizaciones con fines específicos, a veces combinados (comunitarios, gremiales, económicos, culturales, dirigidos al Estado, enfocados al mercado, de reivindicación étnica, de autopromoción en distintos aspectos etc.); 2) Estas nuevas organizaciones involucran diferentes niveles de agregación: pequeños grupos de interés, facciones de linaje, comunidades sucesoriales, comunidades históricas, conjuntos campesinos especializados productivamente, una microrregión cuyos productores se conciertan para algún propósito permanente o los pueblos andinos que plantean reivindicaciones a través de órganos de representación; 3 ) Poseen distintos grados de formalización, desde aquellos con relaciones internas informales y poco definidas, hasta 
organizaciones dotadas de personería jurídica, con estatutos, reglas de funcionamiento y elección de dirigentes; 4) Alcanzan grados de permanencia y estabilidad variables, siendo comunes las organizaciones efímeras que duran hasta que los objetivos para los que fueron creadas se cumplen. Hay otras cuyo diseño y funcionamiento les permite una proyección de largo plazo. En definitiva, la heterogeneidad es el sello distintivo de la agrupación y organización andina de hoy.

Al desarrollo organizacional en el espacio andino indígena, la proliferación de organizaciones en el altiplano y valles bajos, oasis y sectores colonizados, la heterogeneidad y la etnificación de las mismas, la "urbanización" de las organizaciones de productores y de agentes implicados en cuestiones agropecuarias, podemos entenderlos como fenómenos concomitantes con la regionalización o apertura de la sociedad aymara y atacameña a la región. En la medida que tales fenómenos involucran no solo a indígenas, sino a toda la población relacionada con la agricultura regional, más que de regionalización andina debemos apreciarlos como de transformación de las relaciones rurales-urbanas. Ello implica la pérdida de nitidez de esta distinción clásica, y acarrea la deflación de esas categorías para explicar los fenómenos agrarios regionales.

Es posible distinguir tres formas históricas de la organización andina. La primera de ellas, que denominamos de sustrato, es la comunidad andina. En el presente se trata de una cultura y un sistema de grupos y organizaciones, pero no de una estructura tradicional. Como cultura, consiste en disposiciones a actuar colectivamente de ciertas maneras y, como relación social, en algunas instituciones comunitarias operativas y vigentes, pero distantes de las que fueron características en el pasado. Esta situación se explica tanto por el desgaste histórico de las instituciones de gobierno local indígenas como por su reemplazo por nuevos formatos organizativos promovidos desde el Estado. El antecedente histórico son los gobiernos locales indígenas vigentes hasta el siglo XIX, a veces con algunas prolongaciones durante la primera mitad del siglo XX. El sucedente son las organizaciones autónomas de la comunidad y las originadas por inducción estatal, entre las que destacan las juntas de vecinos impulsadas por los gobiernos desarrollistas de mediados del siglo XX, y en el presente, las co- munidades indígenas gestadas con la política indígena iniciada en la década de 1990.

La segunda está representada por las organizaciones locales de base territorial (juntas de vecinos) con un prolongado arraigo en las comunidades andinas. Mientras más se despliega la acción desarrollista del Estado, visible en estas regiones desde 1940 en adelante, más interlocución local presupone. Esta relación por lo general, aunque no siempre o para cualquier prestación del Estado, ha supuesto referentes colectivos. No corresponde con la organización tradicional, sino con aquellos formatos propuestos, estimulados por los organismos públicos: comités y juntas de adelanto local hasta inicios de la década de 1960; juntas de vecinos cuando la política de Promoción Popular de la Democracia Cristiana se instala con fuerza entre 1964 y 1969. Luego, un breve período de proliferación de organizaciones (cooperativas, asentamientos campesinos y centros de reforma agraria) relacionadas con las reformas que en la agricultura intensificó el gobierno de la Unidad Popular (1970-73); más tarde, durante el período dictatorial, se desmanteló la organización campesina de la reforma y reforzó las juntas de vecinos y centros de madres con fines de control político y canalización de algunos recursos. Ya hacia el final del período, entre 1974 y 1999 la propuesta de creación de sociedades de pequeños productores según un formato no específico para el sector campesino y/o indígena. Con el retorno a la democracia se da continuidad a algunas modalidades de organización (p.e., juntas de vecinos), se reactivan otros (p.e., cooperativas, aunque en forma bastante restringida) y se innova (comunidades y asociaciones indígenas, además de una verdadera inflación de agrupaciones ad hoc según los requerimientos de las agencias públicas). Con ello se llega a la heterogeneidad, diferenciación y complejidad presente.

Las entidades que mayor fuerza y continuidad han tenido son las organizaciones locales-territoriales de base comunitaria; en particular, las juntas de vecinos. Esa fortaleza proviene tanto de su fuerza interna, al estar apoyadas en el sustrato de cultura organizacional andino, como de las funciones que externamente las han llevado a prestar diversas agencias estatales, principalmente el municipio. En este sentido, la comunidad local se erige como un eje de estructuración del campo organizativo andino moderno. Como objeto directo de la acción de 
grupos y organizaciones o solo como modelo evocado, la comunidad sigue manteniendo una centralidad indiscutible en las formas de organización, el reclutamiento de los miembros, la definición de las metas, el curso de las trayectorias y la posición relativa de las agrupaciones andinas. También señalan esta persistencia el asambleísmo, la construcción de consensos como recurso de legitimación de las decisiones y acciones, las formas de delegación y representación, las características de los liderazgos y su control por la base. Relaciones múltiples parentales, de pertenencia comunitaria, económicas o religiosas, dan a las relaciones sociales, los grupos y las organizaciones que la integran, una continuidad y profundidad que difícilmente podría encontrarse en otro núcleo sociológico del cual sea partícipe la población indígena andina.

La tercera corresponde a la irrupción étnica que se expande con la organización indígena promovida desde el Estado. Provenientes de las organizaciones indígenas principalmente urbanas que innovaron en la región formulando una identificación étnica, estos nuevos funcionarios posesionados de cargos que les ha permitido el control de la nueva institucionalidad estatal creada para implementar una política indígena -y con la energía de los conversos-, difundieron representaciones étnicas y promovieron la organización que para los pueblos indígenas consideró la nueva legislación. Lejos de haberse dado de un modo fluido y natural, esa difusión de ideas acudió al empleo de violencia simbólica, del mismo modo que la promoción organizativa conllevó imposiciones y hasta coerción, lo que fue posible ejecutar desde la posición de poder que les dio el manejo de las nuevas verdades étnicas y el control de recursos dispuesto para la política indígena.

¿Cómo se relacionan entre sí estos niveles? Hemos dado a entender que hay aspectos de continuidad y complementación, pero también tensiones y contradicciones. Debido a su autonomía y a la relación de algunas formas de organización con elementos propios de las comunidades andinas, podemos asumir que se trata de adaptaciones o extensiones transformadas de formas organizativas de base local y tradición andina (p.e., clubes, centros, cofradías y bailes). Pero, en otras no es así, aun cuando las apariencias parecieran indicar lo contrario. Se apoyan o sobreimponen en ella, pero no son simplemen- te su extensión y desarrollo, aun cuando integren modos y procedimientos de gestión reconocibles como andinos. En esos casos, la comunidad es una plataforma sobre la cual se montan y se desarrollan formas organizativas como juntas de vecinos y comunidad indígena. Definitivamente, no son organizaciones tradicionales. Por ejemplo, las comunidades indígenas se revisten de un aura de tradicionalismo, pero son realmente modernas al responder a una política étnica innovadora en cuanto a la visión, y en parte, a la acción estatal hacia estos grupos regionales. De esta manera, salvo las formas de organización de base local y tradición andina, la organización indígena regional está constituida desde hace décadas de acuerdo a requerimientos externos.

La proliferación se acompaña de un aumento de la heterogeneidad en las organizaciones andinas (económicas, de representación, sociales, culturales, locales y supralocales, autónomas o dependientes del Estado) o con participación indígena andina, tal como lo señalan los Cuadros 1 y 2, así como un cierto grado de diferenciación funcional entre ellas. Se forman órganos encargados de distintas funciones realizadas por grupos parcial o completamente diferentes, lo cual se advierte en la distinción entre organizaciones comunitarias, algunas urbanas, que resultan del desarrollo interno de las localidades andinas, respecto de aquellas que tienen una existencia dependiente de las prestaciones que realizan las agencias estatales. También con las comunitarias fincadas en intereses locales, respecto de las supralocales cuyos intereses son más bien sectoriales, transversales en esa medida a aquellas de las comunidades, pero solo hasta un cierto punto: la tendencia indicada se matiza con la concentración de funciones y de figuras organizativas en la comunidad local. Una misma puede ser un grupo comunal con funciones agrarias, comité de agricultores, congregación ritual, junta de vecinos, comunidad indígena y club deportivo. Ello se explica por razones históricas, ya que las comunidades siempre han sido instituciones polifuncionales, pero también por la relación con un Estado que presiona para la formalización de agrupaciones y estimula la adopción de nuevas funciones cuya base la encuentra en los grupos locales.

La heterogeneidad, diferenciación y concentración existentes llevan a un aumento de complejidad de las relaciones externas e internas en las agrupaciones andinas. La proliferación de organizaciones se realiza en distintos 
niveles de agregación social y con varias modalidades de gestión y representación de intereses. Este mismo incremento de formas organizativas la vive la comunidad translocalizada, producto de una oferta estatal caótica, y a través del desarrollo de modalidades de organización asociadas a la translocalidad. Ello provoca una virtual saturación de la organización local.

Sumado a lo anterior ocurre un cambio de posiciones en el sistema organizacional andino regional. La expansión de las comunidades y asociaciones indígenas andinas tiene lugar desde mediados de la década de 1990 de manera correlativa con la declinación de las asociaciones gremiales, fórmula de representación colectiva de intereses sectoriales que había ensayado expandir el gobierno autoritario la década anterior; y también en paralelo con el reforzamiento de las juntas de vecinos como la más importante organización de base territorial con la que tratan los gobiernos municipales ahora democratizados. Este doble movimiento lleva a la rejerarquización de las comunidades y juntas de vecinos en la medida que adquieren mayor importancia para implementar la política social gubernamental.

En la década de los 90 y en la actual se produce una considerable expansión de la organización étnicamente definida ("comunidad indígena") y la etnificación-etnogénesis de los espacios andinos regionales. Este proceso tiene dimensiones jurídicas, socio-organizativas y simbólicas. La relación con el Estado se lleva a efecto en varios aspectos acudiendo a la condición de indígenas y a las demandas que les son propias según esa toma de posición social. Ello tiene consecuencias en la proliferación de organizaciones, en el aumento de complejidad del sistema de acción colectiva y en tensiones y conflictos, especialmente allí donde la etnificación es parcial o superficial y donde ha quedado definida una estructura multiétnica de grupos.

Un problema visible en la actual organización andina es la coordinación interna. Varias entidades funcionando simultáneamente, con responsabilidades que a veces recaen sobre las mismas personas - con la consiguiente dificultad de gestión y respuesta-, o sobre distintas personas y grupos, a veces disgregados en áreas rurales y urbanas - con las imaginables dificultades de coordinación y dispersión-, ponen en evidencia lo anterior. A ello se agrega la participación de parte o la mayoría de los integrantes en asociaciones más amplias. La imagen que se obtiene es la de un entramado de entidades, compromisos y acción que con frecuencia no logran resolver bien. El aumento de la oferta estatal de recursos y la demanda de participación agrupada, agregada a la autogestión colectiva que le es propia, lleva la acción organizada andina más allá de sus capacidades de coordinación, provocando consecuencias internas como la baja eficiencia y frustración.

Otro problema se dirige a las capacidades de acción y respuesta hacia las agencias públicas que en las últimas décadas aumentan la oferta de servicios y recursos. Compromisos internos diversificados y respuesta externa normalmente plural comprometen la capacidad de acción de las organizaciones andinas (juntas de vecinos y comunidad) y su calidad. Este problema se torna especialmente agudo cuando la demanda sobre la organización implica conocimientos y destrezas especializadas, o nuevas formas de gestión. Buena parte de la inversión pública en las comunidades y localidades indígenas se deteriora y cae en desuso rápidamente, entre otras razones, por la ausencia de competencias técnicas y capacidades de gestión adecuadas a esas innovaciones.

La inducción a la organización local se encuentra con realidades comunitarias que contienen fisuras, divisiones y conflictos internos. La exigencia externa por organización formal se encuentra aquí con un problema, pero esto mismo puede ser tomado como una oportunidad por esos grupos y facciones en función de mejorar sus posiciones de poder interno, controlar relaciones externas y recursos o reabrir focos de conflicto. La comunidad indígena es también fórmula de organización atractiva internamente por las facilidades para su constitución. Grupos familiares y facciones han buscado por esta vía ganar control o, al menos, igualdad de oportunidades para el acceso a recursos del Estado. En estas circunstancias han aumentado las dificultades para una acción estatal expedita. Esta dinámica de organización en relación con las divisiones internas indígenas probablemente no se daría de igual manera de no mediar la abundancia de recursos estatales. Las organizaciones andinas relacionadas con agencias públicas e, indirectamente, la propia organización interna y sus órganos se vuelven marcadamente dependientes del Estado. Muchas de ellas seguramente se disolverían 
de no tener éxito en su función de instrumentos para canalizar recursos financieros, infraestructura, tecnología, servicios básicos, capacitación, información, y garantías frente a terceras agencias. Su fragilidad es evidente pues se trata de organizaciones instrumentales, cuya sustentación y actividad dependen de condiciones externas. No son organizaciones comunitarias autosuficientes o autosustentables. Internamente, la dirigencia y los liderazgos se mantienen solo en la medida que logren concitar la acción estatal y hagan llegar recursos y servicios a sus asociados. Si esto es muy esporádico, poco relevante o se interrumpe, en la misma medida la organización cae en la inactividad. Pero la dependencia es recíproca pues las agencias públicas también requieren de "beneficiarios" o "participantes" de las líneas de desarrollo que promueven, ya que de otro modo manifestarán pobres resultados de gestión, evaluados en consecuencia y arriesgando recortes o suspensiones de fondos. Esto lo perciben los dirigentes, en especial durante los últimos 15 años en que se ha dado una sobreoferta de proyectos y recursos (p.e., en San Pedro de Atacama y en Camiña). De allí que la dependencia tiene en realidad dos caras, lo que eventualmente ha facilitado mejores estándares de negociación.
La organización indígena tampoco es ajena a la dinámica de la política local cuyo núcleo es el gobierno municipal y los recursos y prerrogativas de las comunas, en particular aquellas compuestas completa o mayoritariamente por indígenas de la región aymara y atacameña. De esta manera, la influencia sobre, y el control de, dirigencias de juntas de vecinos y comunidades y asociaciones indígenas es una materia sensible en una competencia política local sobre la que convergen alcaldes, concejales, militantes y agentes de partidos, así como influyentes locales con aspiraciones. Esta búsqueda de influencia encuentra grupos y organizaciones de la comunidad frecuentemente en competencia o con rivalidades, pero también tomas de posición clientelistas o de negociación dirigidas a promover influencias y atraer recursos desde los municipios.

Agradecimientos Este trabajo ha sido elaborado en el marco del proyecto FONDECYT 1085332: "Poder local y movimiento étnico". Agradecemos los comentarios y sugerencias de dos evaluadores anónimos del manuscrito, que nos sirvieron para introducir algunas precisiones y para ampliar el campo de estudio y reflexión sobre sujetos y subjetividades sociales andinas regionales.

\section{$*$ Referencias citadas}

ALBER, E., 1999. ¿Migración o movilidad en Huayopampa? Nuevos temas y tendencias en la discusión sobre la comunidad campesina en los Andes. Instituto de Estudios Peruanos, Lima.

ANDERSON, B., 1993 [1991]. Comunidades imaginadas. Reflexiones sobre el origen y la difusión del nacionalismo. Fondo de Cultura Económica, México D.F.

DIEZ, A., 2006. Redes, organizaciones y movilidad económica en comunidades campesinas (el caso de Huayopampa). Debate Agrario 40-41: 61-84.

FUENZALIDA, F., 1970. Estructura de la comunidad de indígenas tradicional. En Hacienda, comunidad y campesinado en el Perú,J. Matos $\operatorname{Mar}(E d$.$) , pp. 219-263. Instituto de Estudios Peruanos, Lima.$

GONZÁLEZ, H., 1991. Desarrollo organizativo y participación politica reciente entre los aymara del norte de Chile. Serie Documentos de Trabajo, Taller de Estudios Andinos, Arica. 1996a. Características de la migración campo ciudad entre los aymara del norte de Chile. Serie Documentos de Trabajo, Corporación Norte Grande, Arica.

1996b. Las agrupaciones de migrantes aymara urbanos en el norte de Chile: Adaptación a la ciudad y vínculos con las comunidades de origen. Serie Documentos de Trabajo, Corporación Norte Grande, Arica.

GONZÁLEZ, H., H. GUNDERMANN y R. ROJAS, 1991. Diagnóstico y estrategia de desarrollo campesino en la I región de Tarapacá. Serie documentos de trabajo,Corporación Norte Grande, Arica.

GUNDERMANN, H., 2000. Las organizaciones étnicas y el discurso de la identidad en el norte de Chile, 1980-2000. Estudios Atacameños 19:75-91

2001. Comunidad, sociedad andina y procesos sociohistóricos en el norte de Chile. Tesis doctoral. El Colegio de México, México D.F. 
2003. Sociedades andinas, municipio y etnicidad: La transformación de los espacios políticos locales andinos en Chile. Estudios Atacameños 25: 55-77.

2007. Pueblos indígenas y municipios en Chile. En Movimientos indígenas y gobiernos locales en América Latina, W. Assies y H. Gundermann (Eds.), pp. 161-198. Universidad Católica del Norte, El Colegio de Michoacán y Grupo Internacional de Trabajo sobre Asuntos Indígenas, San Pedro de Atacama.

GUNDERMANN, H. y H. GONZÁLEZ, 1996. Organizaciones aymara, identidad étnica e integración. En La integración surandina, cinco siglos después, X. Albó, M. I. Arratia, J. Hidalgo, L. Núñez, A. Llagostera, I. Remy y B. Revesz (Eds.), pp. 395-416. Centro Bartolomé de las Casas, Universidad Católica del Norte y Taller de Estudios Andinos, Cusco.

HIDALGO, J., 2004. Historia andina en Chile. Editorial Universitaria, Santiago.

HOBSBAWM, E., 1983. Introduction: Inventing traditions. En The invention of tradition, E. Hobsbawm y T. Ranger (Eds.), pp. 1-14. Cambridge University Press, Cambridge.

MALENGREAU, J., 1992. Espacios institucionales en los Andes. Instituto de Estudios Peruanos, Universidad Libre de Bruselas, Lima.

2004. Continuidades y restructuraciones identitarias y solidarias entre provincia rural y Lima metropolitana a partir de dos pueblos andinos. Revista Andina 38: 181-199.
2007. Migraciones entre lo local y lo regional en los Andes peruanos: Redes rural-urbanas, fragmentaciones espaciales y recomposiciones identitarias. Bulletin de l'Institut Français d'Études Andines 36 (3):427-445.

MOSSBRUCKER, H., 1990. La economía campesina y el concepto "comunidad": Un enfoque crítico. Instituto de Estudios Peruanos, Lima.

SERPLAC, 1991. Estrategia de desarrollo regional. Servicio de Planificación Regional, I región de Tarapacá (SERPLAC), Iquique.

STEINHAUF, S., 1991. Diferenciación étnica y redes de larga distancia entre migrantes andinos: El caso de Sanka y Colcha. Bulletin de l'Institut Français d'Études Andines 20 (1): 93-114.

TUDELA, P., 1992. Transformación religiosa y desintegración de la comunidad aymara tradicional en el norte de Chile. Holos Verlag, Bonn.

1993. Cambio religioso y revitalización de la comunidad entre los aymara de Arica (1960-1990). Nütram IX (33): 15-48.

URRUTIA, J., 2003. Cambios y permanencias comunales en medio siglo: Revisita a un texto olvidado. Debate Agrario 35: 183-194.

VAN KESSEL, J., 1992 [1981]. Holocausto al progreso. Los aymara de Tarapacá. Hisbol, La Paz. 